\title{
The Overview of E-commerce Development in China: From Consumer's Perspectives
}

\author{
Hleb Dabrynin \\ Huazhong University of Science and Technology \\ Jing Zhang \\ Huazhong University of Science and Technology
}

E-commerce has expanded rapidly over the past five years and still has great potential for growth. The ecommerce industry in China is growing faster than in other countries. This article investigates the ecommerce development in China and provides strategies for foreign companies to enter the e-commerce market. This research study aims to analyze the process of development e-commerce and identify the portrait of the online consumer in China. An exploratory research design is used to highlight the shopping habits of consumers and new emerging segments in the e-commerce market. The successful Chinese experience of e-commerce adoption was analyzed.

Keywords: E-Commerce, Purchase Behavior, Retailers, Product Category

\section{INTRODUCTION}

The electronic commerce popularity came last few years ago and together with the Internet boom in the 1990s has changed the way businesses interact with their customers. The modern information and communications technology (ICT) is transforming the way how retailers and consumers buy, distribute, and customize products. The development of the World Wide Web and online commerce during the last two decades have transformed the way of business deal with their customers. In the years to come, ecommerce (including mobile and social commerce) is expected to be one of the most important factors of growth in a competitive business environment. Business-to-business (B2B) e-commerce is six times larger than business-to-consumer (B2C) e-commerce. Global e-commerce totaled 2.8 trillion USD in 2018, up from 1.3 trillion USD in 2014. The USA and China have the largest economies in the world, and both of them are dominating global online retailing. These two countries are responsible for more than half of the worldwide online sales of goods during the 2018 year (Statista, 2019). (Statista, 2019). According to China's Ministry of Commerce (2019), China is number one in the world's e-commerce market, China's online sales reached 894.1 billion US dollars in the first three quarters of 2018 with a year-on-year increase of 27 percent. Specifically, e-commerce in China characterized by advance and fast growth in the ICT marketplace, the highest increase in Internet penetration, strong retail sector, and young population. 
China's e-commerce development has main stages: acceleration, standardization, and globalization stage. Some scholars, Yuxin and Liang (2016) state that there are six stages: germination, growth, accelerate, mature, outbreak, and transformation. Based on the research of Ming and Zhongtao (2017), need to distinguish four stages: independent, platform, ecological and value. According to the previous research work, this study divides e-commerce development into three stages. Consumers have become an essential driving force in the e-commerce market in China. The middle class and the massive demand for international products are facilitating the proper conditions of China's online commerce. Despite that, the Chinese government implemented a legislative background to enhance e-commerce market growth on a large scale.

There are still considerable obstacles experienced by foreign businesses, which enter China market to bring investment to the e-commerce sector, and these obstacles will be analyzed in the paper. Thus, this study contributes to the literature by providing foreign companies with important strategies for the ecommerce market in China. McDonald (2007) describes the strategy as the way to the accomplishment of specific objectives and defines how objectives will be attained. Although electronic commerce between companies (B2B) represents about $90 \%$ of total e-commerce financial affairs, the research paper will focus on barriers of $\mathrm{B} 2 \mathrm{C}$ e-commerce adoption, since this segment has higher potential and is closer to consumer purchase behavior. No studies have been found focusing on e-commerce development from the consumer's perspective in China. This study also contributes to the marketing literature by analyzing consumer behavior in the Chinese market and providing meaningful insights. Chinese experience and innovations in e-commerce adoption show an excellent example for developing counties to build ecommerce infrastructure and establish legislative policy in order to have the stable growth of the ecommerce market. The research paper opens with a review of the marketing literature in e-commerce development as well as the investigation of online purchase behavior, followed by the findings and a conclusion.

\section{ELECTRONIC COMMERCE IN THE PEOPLE'S REPUBLIC OF CHINA}

Due to the fast development of the Internet and the mobile infrastructure, the digital economy has rapidly grown in China. ICT is one of the most advanced market sectors in the Chinese economy. China is the world's second-largest ICT market. China's ICT market will reach $\$ 844$ billion by 2020 (Export.gov, 2017). With ICT advancement, China has also developed the necessary legislative infrastructure for electronic transactions. Although the primary Internet use is related to physical infrastructure, thus to some degree explaining this variation, e-commerce activity is significantly characterized by reliance on the institutional environment (Oxley \& Yeung, 2001). The government of China has established a series of e-commerce laws, regulations, and directives to promote the development of e-commerce. In 1999, the first time China manifested the "Contract Law" to accept the legality of information messages. The State Council, via the "People's Republic of China Telecommunications Regulations," controls the telecommunications traffic and increases the oversight and management of Internet materials and services in September 2000 (Wu, 2017). In June 2000, certificated by the government, the China Electronic Commerce Association was officially established. This event was not only a recognition of e-commerce as a specific industry, but also marks e-commerce's accelerated development. In October 2005, the People's Bank of China issued the "electronic payment guidelines." In January 2006, the China Banking Regulatory Commission promulgated the "electronic banking business management approach" and "e-banking security assessment guidelines" to establish legislative boundaries in e-commerce (Wu, 2017). Therefore, the early 2000s was named an accelerated stage of China's e-commerce.

In China, the standardization stage of electronic commerce started from 2008 to 2014. China's massive consumer market gave excellent benefits for e-commerce development. China has become the world's largest e-commerce market with $\$ 458$ billion in sales in 2014, according to Kantar Retail (2015). In 2014, Chinese e-commerce showed $19.4 \%$ of GDP growth and reached almost $33.5 \%$ of total retail growth. Moreover, the mobile payment system started to use widely in China that made an 
enormous contribution, especially for B2C e-commerce sector. Even though m-commerce is extracted from e-commerce, and they have common features and functions, there are still significant differences. The main difference between them is that mobile commerce allows purchasing a product via wireless manual gadgets, such as mobile phones, notepads and personal digital assistant (PDA). Mobile commerce has the main benefit that includes the capability to finish traditional e-commerce transactions by using a wireless connection. In China, the development of mobile communications has shown the fastest growth and finally turned into the largest mobile market in the world.

All Chinese online retailers have started to focus more on consumer's smartphone and tablet applications. Mobile commerce definitely has its advantages and functionalities, and companies could have an advantage from it by successfully adapting $\mathrm{m}$-commerce applications. Consumers have started to use mobile devices at any time and any place, which gives m-commerce companies an excellent opportunity to obtain a large amount of consumer and transaction information, to make a better business decision. Successful implementation of m-commerce helped to reduce process errors, response time, and cut organization costs, and finally to increase the efficiency of business processes. That's why ecommerce companies focused on Chinese consumers and didn't enter the overseers market. Chinese consumers' purchase activity has played an increasingly prominent role in boosting the e-commerce development and increasing profit of the retailers, and the potential of demand for new products and services continues to rise.

The Government of China has performed a crucial role in the progress of e-commerce, in terms of establishing a good atmosphere for e-commerce to prosper and support the information technology sector by putting the correct regulations and policies. China continued to launch e-commerce regulatory policies. In 2011, the State Council developed "the Guiding Opinions on the Development of E-commerce at the 12th Five-Year Plan," and "the Guidance on the Establishment of National E-commerce Demonstration Base," and finally "the Third Party E-commerce Transactions Platform service specification" (Lin, 2017). These laws helped to enhance China's e-commerce market development and prepared Chinese ecommerce retailers to enter the global market. According to a new eMarketer report (2019), the Chinese e-commerce market has started to increase quickly during the period 2014-2019 years.

FIGURE 1

\section{RETAIL E-COMMERCE SALES IN CHINA, Bn. USD}

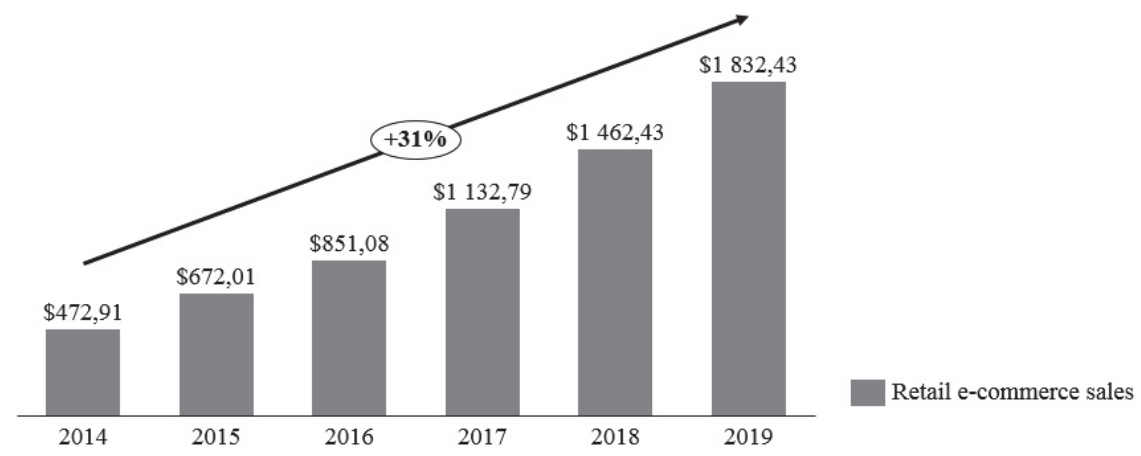

Source: eMarketer (2019)

Data includes products or services ordered using the Internet via any device, regardless of the method of payment. As shown in Figure 1, retail e-commerce will reach \$1832,43 billion this year, up $20.2 \%$ from 2018. The compound annual growth coefficient is a helpful standard of growth over numerous periods. The indicator shows stable annual growth of about $31 \%$ through the 2019 year. At the same time, Chinese online retailers are also faced with two main challenges. First, electronic consumers have more complex characteristics than traditional consumers. Because e-commerce occurs in the online space, the transaction behaviors differ from those in the offline transaction system. Second, in the process of e- 
commerce, sellers and buyers conduct their businesses through the internet without face-to-face communication; the consumers primarily rely on the visual impact of the web sites design. Moreover, the various regions in China differ greatly in terms of e-commerce consumer demand and e-commerce business models, and sometimes it's hard for e-commerce to predict consumer behavior during online shopping.

Customers are the main drive force of e-commerce in China. The consumer study introduces that China's tremendous consumer market is as astonishing and fast-growing as ever. There are four generations of consumers in China: the first generation from the $1950 \mathrm{~s}$, the second one was born in the 1970s, the third generation of consumers was between 1980s and 1990s and the fourth generation was born after 1995, which are the most active when it comes to online and mobile purchases. The Chinese millennials are determined to be the supreme force and the strongest consumer segment in the market place. Goldman Sachs (2015) relates to Chinese millennials as "the unique most vital generation in the world today." Millennials make up more than 400 million people, which is more than the total working population of the USA and Western Europian countries. In China, this group represents almost a third of the population. By 2020, millennials will become more than a third part of the Chinese urban population (Eshopworld, 2019). Millennials are the first age group to have grown up among political strength, fast economic growth, and extending global connection. According to the Boston Consulting Group (2015), consumption by young Chinese people under the age of 35 accounts for $65 \%$ of consumption growth. With a good level of income, Chinese millennials will consume more of the world's brands in almost every category.

FIGURE 2

\section{CONSUMPTION BY MILLENNIALS AND OLDER GENERATIONS, Tn. USD}

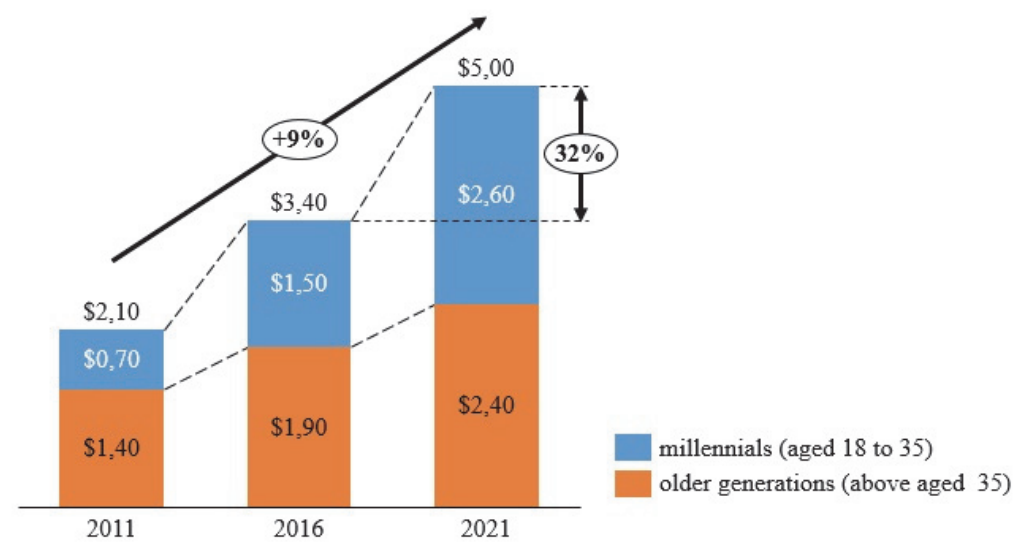

Source: Boston Consulting Group (2015)

According to Figure 2, total consumption by millennials and older generations will reach 2,6 trillion and 2,4 trillion USD respectively by the 2021 year. Moreover, Boston Consulting Group estimates that the annual growth rate from the 2011 year close to 9 percent. The total consumption by the young generation and older generations are projected to reach 5 trillion USD by 2021, up $32 \%$ from the 2016 year. Furthermore, Fund Business Intelligence's report (2018) states that consumption by these young consumers is growing at an annual rate of $11 \%$ from 2016 to 2021 - twice older consumers at the age of 35 . The total consumption by millennials will hit $52 \%$ by 2021 , versus $48 \%$ by the older generations.

A study by Zhou et al. (2011) examines the factors that increase and decrease online Chinese consumers' purchasing. Scientists discover that perceived positive service quality has a significant influence on consumers' increase in online purchasing while perceived poor website quality resulted in a decrease in online purchasing. Zhou et al. (2011) suggest that e-retailers should be mindful that different strategies must be pursued if the desired effect is to increase online shopping or reduce online shopping 
defectors. According to Accenture's report (2018), there are two main factors, which can create new purchasing power and consumer patterns. The first one is the vast digital ecosystem that is now putting more money in the wallets of consumers and the second one is to make it easier for consumers to spend money. Now around $40 \%$ of consumers receive additional revenue by selling products through online platforms such as Wechat and Taobao. This is one of the main reason for consumers in China to increase their spending in the nearest future. Mobile payment, credit, and financing options are the main methods for consumers to spend without having cash in hand. These techniques inspire consumers to purchase products more impulsive and increase the level of spending. Now Singles Day has evolved into China's biggest non-holiday celebrated by online shopping. This day was originated in China in the 1990s and now is celebrated each year on November 11. Nielsen's up-to-date investigation (2018) displays that consumers have a great passion for the 11.11 shopping holiday, almost $94 \%$ of online consumers in China have taken part in online shopping activities. Consumers with a broader range between 18 till 35year-old were the main purchasing power, and apparently had an impulsive purchase behavior, so online consumers born in the 1980s (56 \%) and consumers born in the 1990s (58 \%) said that they unexpectedly made purchases. An increasing number of global Internet users, as well as improved systems of crossborder payment, logistics, and other services, China's cross-border e-commerce retail overseas consumer business (B2C/C2C), started to grow significantly. Several cross-border e-commerce platforms, such as Ali Express, JD.com have a significant impact on the e-commerce market. Besides that, these online retailers began to directly participate in international trade, which was the first sign for transition Chinese e-commerce into the globalization stage.

The globalization period of e-commerce in China started from 2014 until the present time. In April 2014, Chinese companies established the road to creating an Initial Public Offering (IPO) on the New York Stock Exchange. JD.com went public on Nasdaq in May, becoming the second-largest business platform in China. Alibaba was in the investment list of the New York Stock Exchange in September and became the largest IPO in American history. It can be stated that the most powerful year for China's global e-commerce was 2014 year. The online retail industry is in permanent growth since 2014. Based on Internet Retailer report (2019), at the present time, the list of top ten worldwide online retailers includes Amazon.com, JD.com, Suning Commerce Group, Apple, Walmart, Dell Technologies, Vipshop Holdings, Otto Group, Gome Electrical Appliances and Macy's (see Table 1). The top five online platform net sales reached more than $\$ 200$ billion in 2018. Out of the top five world e-retailers, three of them are located in the USA and two are Chinese natives (Internet Retailer, 2019).

TABLE 1

THE TOP 10 GLOBAL E-COMMERCE RETAILERS IN 2018

\begin{tabular}{|c|c|c|c|c|}
\hline Rank & Retailer & Country & Merchant Type & Merchandise Category \\
\hline 1 & Amazon.com & USA & Web-only & Mass Merchant \\
\hline 2 & JD.com & China & Web-only & Mass Merchant \\
\hline 3 & Suning Commerce Group & China & $\begin{array}{l}\text { Retail Chain } \\
\text { Consumer Brand }\end{array}$ & Mass Merchant \\
\hline 4 & Apple & USA & Manufacture & Consumer Electronics \\
\hline 5 & Walmart & USA & $\begin{array}{l}\text { Retail Chain } \\
\text { Consumer Brand }\end{array}$ & Mass Merchant \\
\hline 6 & Dell Technologies & USA & Manufacture & Consumer Electronics \\
\hline 7 & Vipshop Holdings & China & Web-only & Mass Merchant \\
\hline 8 & Otto Group & Germany & Catalog $\backslash$ Call Center & Mass Merchant \\
\hline 9 & Gome Electrical Appliances & China & Retail Chain & Mass Merchant \\
\hline 10 & Macy's & USA & Retail Chain & Apparel $\backslash$ Accessories \\
\hline
\end{tabular}

Source: Internet Retailer (2019) 
The Chinese opponent of mass retail industry JD.com Inc., which both trades its goods and promotes sales for international retailers, came in at №2 position in the coming ranking list. Internet Retailer report (2019) states that large mass sellers such as eBay Inc. and Alibaba Group and Tmall online retailer are eliminated from this ranking system because they work as ordinary marketplaces and they don't possess any inventory - rather provide third parties with their platform.

The globalization stage is characterized by the implementation of new technologies in the ecommerce market. Internet broadcast speed upgraded significantly in 2016, and the total number of $4 \mathrm{G}$ subscribers went beyond 734 million. Now China has the edge with 5G. According to the Chinese Academy of Information and Communications Technology (2018), 5G technology will establish more than 8 million job positions inside the country by 2030. China is involved in $5 \mathrm{G}$ global standards and a lot of national companies start to use the trials of $5 \mathrm{G}$ technology. First of all, China wants to use $5 \mathrm{G}$ in ecommerce. A good case is Xiong'an, a new city that the government is constructing near the southwest of Beijing to decrease crowding in the capital. China Telecom and China Mobile have already set up a network there to test 5G capability. Qian Liu et al. (2017) states that 5G as a transformative technology requires very high carrier frequencies with numerous base stations and antennas. It will also drastically affect private lives with the deployment of 5G-based social applications such as the Internet of Things (IoT). Anyway, telecommunication operators, such as China Mobile, China Telecom, and China Unicom, have been transforming themselves to accommodate the IoT. The IoT is a smart network which links all things to the Internet for the aim of interchanging information and contacts through the sensors of devices in agreement with given protocols. It accomplishes the goal of intelligent identifying, locating, tracking, monitoring, and managing things (Stankovic, 2014). China has favorably created advanced technologies such as virtual reality (VR), augmented reality (AR), and artificial intelligence (AI) (Export.gov, 2017).

Since China's present trade framework was built before the emergence of variety cross-border online commerce transactions, China has established up-to-date cross-border e-commerce test zones in 13 urban areas since 2015, which has led to significant growth and has just authorized 22 more positions throughout Chinese territory (China.org.cn, 2018). Cross-border online commerce relates to transactions among consumers and suppliers in many countries through online commerce platforms, employing crossborder logistics for the distribution of products (Chen \& Yang, 2017). These pilot zones contribute an update system with simplified rules for quick examination and consent, custom clearance, and clear information splitting for cross-border e-commerce exports and imports. Wang et al. (2017) estimate that by 2020, the revenue of China's cross-border e-commerce transactions will reach 12 trillion yuan, accounting for $37.6 \%$ of total import and export. The Chinese executives make attempts on the progress of test zones because they view cross-border e-commerce as an essential step in raising new growth drivers and enhancing the country's worldwide competitiveness. Moreover, Chinese online retailer such as Alibaba Group also promotes unique online commerce zones in countries such as Malaysia and Thailand (SCMP, 2018). JD.com has issued plans to construct 185 drone airports in the Southwest part of China to employ for the goods distribution (World Economic Forum, 2018).

Every consumer in China faces with the same high-quality service while he desires to purchase a product online. This is a huge benefit of a centralized system. In China, it is not necessary to create many accounts to purchase a product from any retailer. It's likely to obtain virtually any product from any company via one account due to Alibaba Group supplies with whole main resources, to all merchants. The Chinese online commerce has received this combined system since they accepted to have the supremacy of Alibaba Group and all other merchants are ready to deal with Alibaba. Contrariwise, in the United States and other countries, no one is prepared to admit the domination of any other retailer or company. One more improvement in Chinese online commerce is that online platforms are the places where consumers can buy foreign products. They have the choice to purchase online such Western items, which they want to buy. Moreover, delivery service in China proposes maintenance that is much cheaper compared to the cost introduced in Western markets.

It is not so easy to understand the secret behind online commerce achievement in China. A lot of people consider that Alibaba and JD.com are mainly responsible for the successful adoption of ecommerce in China. But there are many other factors, such as government legislative policy and 
economic support to build the necessary infrastructure for e-commerce development. It seldom seems researchers pay attention to government regulations when they research the development of e-commerce, but this article indicates that Chinese government regulations impact e-commerce growth heavily. In order to maintain the healthy development of e-commerce in China, the government has done plenty of measures for successful e-commerce adoption. The government established relevant legislation and strengthen market discipline regarding e-commerce in China, especially to overcome the challenges of $\mathrm{m}$ commerce, social commerce, and cross-border e-commerce. The success of electronic commerce in China is also due to a combination of advanced digital technology and cultural trends. Thus, China has its own operating systems, smart mobile devices, software tools, mobile applications, and fast internet connection. All these facilities enable a large number of Chinese people to purchase online conveniently.

\section{ONLINE PURCHASE BEHAVIOR IN IN THE PEOPLE'S REPUBLIC OF CHINA}

One of the main challenges facing e-commerce organizations is the shopping habits of Chinese consumers. It seems that Chinese consumers are transformed into status-conscious and smart, which could contribute to the growth of e-commerce. Nevertheless, if consumers make the final purchase decision via the Internet or through a physical store, most Chinese buyers search online for price differentiation before they purchase. Chinese shoppers search for bargains, looking at several websites before making a purchase. A research investigation announced by The Nielsen (2018) discovers that approximately $39 \%$ of Chinese consumers are ready to "purchase good quality products with comparatively higher cost." On the other hand, Chinese consumers $(24 \%)$ would search for good quality transactions on the desired products. Moreover, $31 \%$ of consumers claim that they would purchase the retail membership that gives price cut and $65 \%$ would operate services for shopping together and other online platforms that provide discounts. In China, consumers compare to foreign countries even prefer to buy clothes online than shopping in traditional retail outlets.

\section{FIGURE 3 \\ ONLINE PURCHASING: PRODUCT CATEGORY IN CHINA}

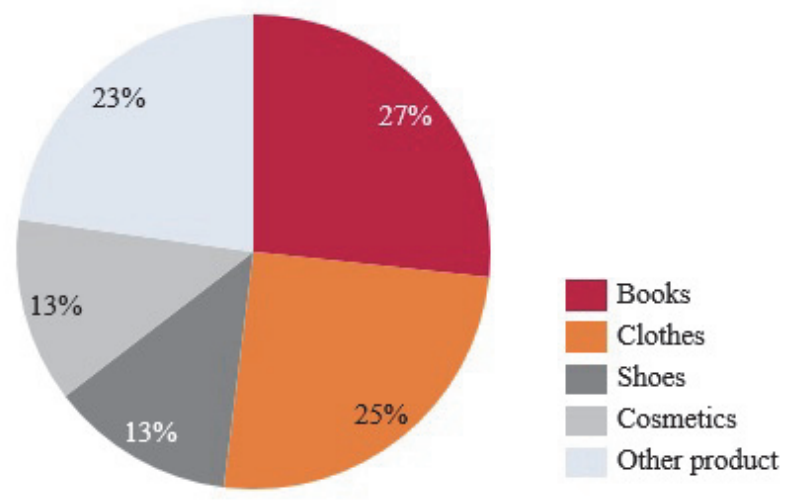

Source: Zhao (2015)

Figure 3 above illustrates the key product categories for online sales. Research conducted by Zhao (2015) states that clothes $(25 \%)$ and books $(27 \%)$ are the most popular products on the Internet. Shoes (13\%), cosmetics (13\%) and other things (23\%) have also good demand in China. In June 2014 another survey found that nearly three-quarters of digital buyers said they preferred shopping online to shopping in traditional retail outlets. That's why e-commerce in China became "lifestyle," and many online retailers only paid attention to the domestic market (eMarketer, 2014).

According to the Global Retail Report (2016), the most frequent product categories in China are clothing, computers and digital products. Frequency shows how often consumer buys in each category 
(see Table 2). Frequencies of the product are not related to the volume of sales and only describe how often a consumer search for those items to buy it.

TABLE 2

THE TOP PRODUCT CATEGORIES PURCHASED FREQUENTLY

\begin{tabular}{lclc}
\hline Category & Frequency & Category & Frequency \\
\hline Clothing / Accessories & $75,6 \%$ & Cosmetics & $30,6 \%$ \\
Computers / Digital products & $45,3 \%$ & Books / Audiovisual & $25,7 \%$ \\
Household Items & $45,1 \%$ & Appliances & $22,7 \%$ \\
Virtual Products / Travel & $34,9 \%$ & Fashion and Beauty & $22,4 \%$ \\
Bags / Suitcases & $32,7 \%$ & Stylistic Supplies & $18,0 \%$ \\
\hline
\end{tabular}

Source: Global Retail Report (2016)

Nowadays, Chinese e-commerce reaches maturity in the categories mentioned above, while growth opportunities in other categories become higher. In Western countries, online grocery still not a popular issue, but it has huge potential in China. According to Agriculture and Agri-Food Canada (2017), Chinese consumers prefer to search for grocery products online and buy them online (see Figure 4). China possesses not only the largest online marketplace all over the world but also the biggest online grocery market in the world having $\$ 23.9$ billion in 2016. Online grocery is the main challenge for retailers worldwide, but this is a good opportunity for China.

\section{FIGURE 4}

\section{CHINESE AND GLOBAL METHOD TO SEARCH AND PURCHASE GROCERY}

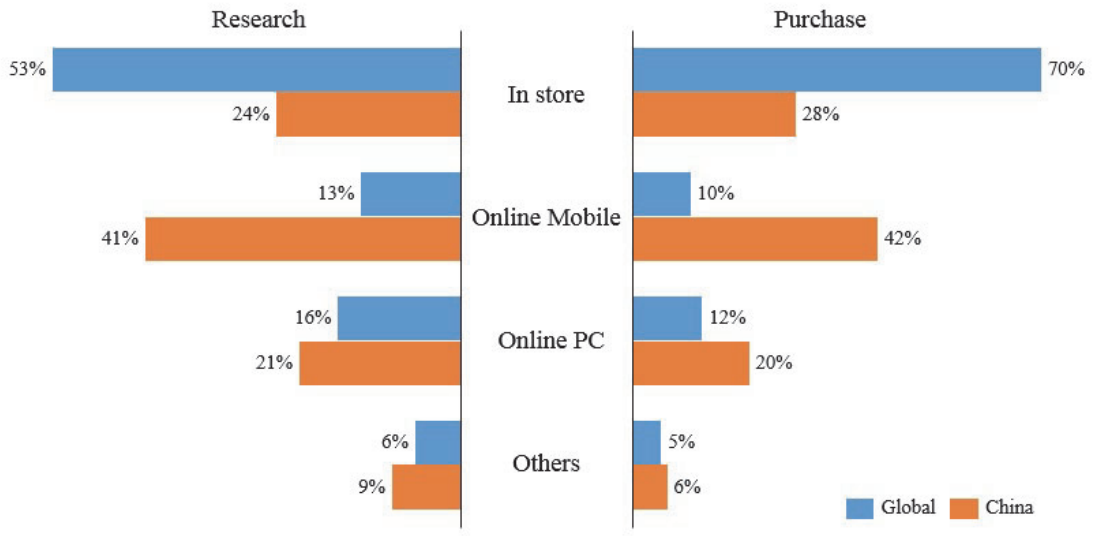

Source: PwC Total Retail (2017)

E-commerce leading companies JD.com and Alibaba have included grocery to their broad online shopping stores. Alibaba Group and JD.com have made important signals in the Chinese online grocery market, and now they are dominating in that channel with original brick-and-mortar shops that integrate sensory experience with bleeding-edge digital characteristics.

Chinese luxury market enjoys robust growth. The luxury market is accelerating by millennials, especially those from the fast-growing middle class. Millennials start buying luxury products when they are young - approximately ten years younger than youngsters in Europian countries and 20 years younger than people in the United States. Based on the Fund Business Intelligence report (2018), it is also anticipated that by 2024, millennials will explain around $50 \%$ of China's luxury market. Chinese consumers are account for a third of the $\$ 1$ trillion in worldwide demand for luxury products. 
International brands have recently come to online platforms making attempts to working with Chinese consumers, especially as they depend on the portals to reach Chinese consumers.

McKinsey's report (2019) states that the percentage of purchase volumes from Chinese consumers will increase from $19 \%$ to $40 \%$ of the individual luxury market (see Figure 5).

\section{FIGURE 5 LUXURY GOODS MARKET EVOLUTION, Bn. RMB}

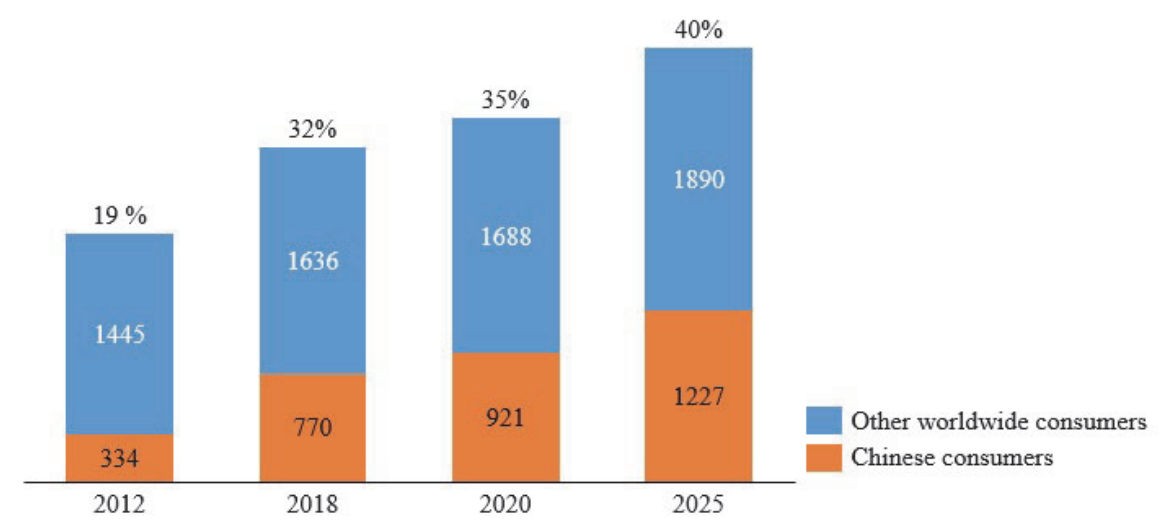

Source: McKinsey (2019)

Nevertheless, the luxury market still continues to focus on offline experience. According to the McKinsey survey (2019), offline store experience is the most constantly reported as the source of information for luxury consumers. Nevertheless, the percentage of online sales volume in the Chinese luxury marketplace is increasing quickly from $8 \%$ to $12 \%$ by 2025 . Chinese luxury buyers, regarding purchasing channels, differ so much compared to Western fellows. Chinese consumers are more apparent to purchase luxury goods on common online platforms such as Tmall or JD.com $(51 \%$ in China compared to $23 \%$ in the West). Luxury consumption is embedded in various cultural contexts. Wong and Ahuvia (1998) state that Asians' luxury consumption is mainly influenced by factors including Confucian collectivism, individual or group needs, values of being modest and thrifty, among others. "Saving face" can be an essential motive justifying Asian consumers' powerful desire for luxury products in opposition to the average income (Zhou \& Belk, 2004; Zhou \& Nakamoto, 2000). Noted as "the optimistic social value a person efficiently demands for himself to avoid having other people lose respect for themselves" (Goffman, 1967, p. 5), saving face concept plays a more outstanding and sincere role in Chinese culture as opposed to Western culture (Ho, 1976).

In many countries, companies understand the importance of social platforms for the consumer. Social media includes a large series of word-of-mouth online types (Huffaker, 2006) and the new type is continuing to appear. In recent times social platforms enabled customers to make online purchases and has aided in the sustenance of commerce globally (Weber, 2007). In China, this issue becomes very cruel. The most popular social platforms in China: Wechat, Weibo, Tencent QQ, Youku. Consumers and companies can buy and sell products by using these social platforms. According to PricewaterhouseCoopers (PwC) Total Retail Report (2017), Chinese consumers use social media resources to find out new products and brands (45\% against $39 \%$ globally), confirm the product quality through survey, opinions and feedback (54\% versus $47 \%$ globally), get product directly through a social channel (25\% versus $15 \%$ globally) and after that write a report about the product or experience (27\% against $20 \%$ globally). Based on a mutual study published by Walkthechat (2019), approximately $54 \%$ of the invention touchpoints occur in the Internet network: either through social media, another via digital way, or online word-of-mouth. That's why for retailers and brands to build and participate in social communities and connect with consumers using the social network during online shopping is very cruel. 


\section{DISCUSSION AND CONCLUSION}

After review e-commerce development and online purchase behavior in China, it is important to create and discuss the strategies, which can apply to foreign companies. Nowadays, the Chinese market is open for foreign investors and these strategies will help them to be successful in the e-commerce market. According to the context of this paper, e-commerce in China differs from the Western market not only because of the cultural aspect but also the taste and needs of Chinese consumers are not the same. Companies require to pay their attention to product categories, which are popular among customers especially important product categories of millennials, who represent almost a third of China's population. New emerge e-commerce product categories such as grocery and luxury give foreign companies a good opportunity to establish leadership in these markets. That way, it's cruel for companies to prepare their strategies and practices to adapt to different cultures, legal frameworks, geographic regions, and consumer's category context and to invest ahead of others to ride the highest growth waves. Companies that want to drive their global growth by taking advantage of the immense opportunities presented by China's developing consumer markets will need to be concrete in their market goals and willing to reformulate their strategies accordingly. A business should choose the main product category and the mainstream consumer to get global growth from China.

Social platforms are relatively connected with an online purchase in China. Social media establish strong communication between consumers and organizations and also improves customer service relationship in e-commerce. So, therefore, social media is considered a quite good tool for organizations. Foreign companies should build social marketing as a form of direct marketing which utilizes electronic means to deliver commercial messages to the social media audience. This strategy will allow companies allows to make an excellent email marketing campaign, which helps to enhance goods and service sales, adapt to the market needs of customers and improve business by using consumer feedback and introduce new products and services to the customer after analyzing their needs and wants. Thus, it is imperative that marketers and firms should adopt social marketing as a strategy in reaching their target audience effectively.

Although China's e-commerce ecosystem is complicated, foreign companies should focus on understanding the marketplace platforms and identifying a strong trade partner to work with. Find a reliable business partner in the e-commerce sector is very cruel and could affect the company's market strategy. A business partner can manage the store page of a retailer in a marketplace platform according to customer needs in China. Typically, strategies with Chinese company represent three approaches: a partnership with local vendors or agencies, creating a local team with China, launching via third-party marketplaces and branded sites. The government encourages foreign companies to build strong relations with local business. For instance, e-commerce-related licenses are rarely given to international companies, leading them to form joint ventures with local partners. When establishing a new localized version of your product in China, it's essential to ensure that consumers will find, read about it and finally make the decision to purchase online. A good approach could be to hire a local team to support your customers on your behalf with a local presence. This approach saves your money, time and efforts to build a regional office. Other advantages from the implementation of this strategy are: full control of operations and intellectual property, be close to consumers and new trends in the e-commerce sector. Currently, access to the e-commerce market in China, however, brings a variety of challenges for the foreign company. The third-party agency could help to eliminate challenges for international investors. Only trustable third-party market is vital to establish a connection with intelligent Chinese consumers and prevent wasting essential resources. Nowadays, the third-party marketplaces the by Suning, Alibaba, and JD.com in China. For example, Alibaba helps Tmall Global to become "fast track into China," and numerous foreign companies can think about this third-party marketplace as a way to test products in a new market before completely set up a physical presence.

This paper investigates the e-commerce development in China from consumer perspectives. The ecommerce market has great potential, especially the aspect of online shopping, but before every move of development, we must understand the key factors, which push e-commerce up to the next level. The 
consumer is the main drive force of e-commerce development. Besides that, China has a good legislative system of e-commerce, which organizes government work to promote and guide private entities for sustainable e-commerce growth. Government departments protect the e-commerce market supply balance and stable operation, safe and efficient responsibility to rise to the level of laws and regulations, improve the e-commerce industry macro-control system.

According to the results of deep marketing analysis, this study is not only important for particular companies but also for the global economy, since Chinese e-commerce is driving global economic growth. Future research should focus on comprehensive science concerning e-commerce adoption and examine cross-border online commerce from both consumers and global retailers' perspectives. Research should concentrate on identifying urgent internationals market problems, which can be regulated by the government as a policymaker. Consumers' demand and government agencies together are transforming China's e-commerce market at a pace and scale unprecedented in history and elsewhere.

\section{LIST OF ABBREVIATIONS}

Artificial Intelligence (AI)

Augmented Reality (AR)

Business-to-Business (B2B)

Business-to-Consumer (B2C)

Consumer-to-Consumer (C2C)

Gross Domestic Product (GDP)

Information and Communications Technology (ICT)
Initial Public Offering (IPO)

Internet of Things (IoT)

Personal Digital Assistant (PDA)

PricewaterhouseCoopers (PwC)

South China Morning Post (SCMP)

United States of America (USA)

Virtual Reality (VR)

\section{ACKNOWLEDGMENT}

Thank you, my supervisor, Prof. Jing Zhang for important advice, motivation, and patience during the research process.

\section{REFERENCES}

Alibaba backs free trade with smart digital hub in Thailand. (2018). South China Morning Post. Retrieved July 17, 2019, from https://www.scmp.com/week-asia/business/article/2142495/alibaba-backsfree-trade-smart-digital-hub-thailand

An Introduction to E-Commerce in China. (2016). Global Retail Report. Retrieved July 19, 2019, from $\mathrm{http}: / /$ thegrinlabs.com/wp-content/uploads/2017/05/China-eCommerce-Guide2016.pdf

Capturing Growth in China: New Consumers. (2018). Accenture. Retrieved July 16, 2019, from https://www.accenture.com/t20180628T105043Z_w_/cr-en/_acnmedia/PDF-81/AccentureCapturing-Growth-China-New-Consumers.pdf

Chen, N., \& Yang, J. (2017). Mechanism of government policies in cross-border e-commerce on firm performance and implications on m-commerce. International Journal of Mobile Communications, 15(1), 69. doi:10.1504/ijmc.2017.080578

China Digital Luxury Report 2019. (2019). Walkthechat. Retrieved July 21, 2019, from https://walkthechat.com/china-digital-luxury-report-2018/

China Luxury Report 2019. (2019). McKinsey. Retrieved July 20, 2019, from https://www.mckinsey.com/ /media/mckinsey/featured\%20insights/china/how\%20young\%20chi nese $\% 20$ consumers $\% 20$ are $\% 20$ reshaping $\% 20$ global $\% 201$ uxury/mckinsey-china-luxury-report2019-how-young-chinese-consumers-are-reshaping-global-luxury.ashx

Chinese Millennials. (2019). Eshopworld. Retrieved July 14, 2019, from https://www.eshopworld.com/news/chinese-millennials/ 
China - Technology and ICT. Export.gov. Retrieved July 12, 2019, from https://www.export.gov/article?id=China-Technology-and-ICT

China to set up new comprehensive cross-border e-commerce pilot zones for greater opening-up. (2018). China.org.cn. Retrieved July 17, 2019, http://www.china.org.cn/business/2018-

07/14/content_56840820.htm

E-commerce in China - future is already here. (2017). PwC Total Retail. Retrieved July 19, 2019, from https:/www.pwccn.com/en/retail-and-consumer/publications/total-retail-2017-china/total-retailsurvey-2017-china-cut.pdf

E-grocery market in China. (2017). Agriculture and Agri-Food Canada. Retrieved July 19, 2019, from http://www.agr.gc.ca/resources/prod/Internet-Internet/MISB-DGSIM/ATS-SEA/PDF/e-grocerymarket-china-marche-des-epiceries-en-ligne-en-chine-aug17-eng.pdf

$11.11-94 \%$ of online consumers in China have participated in shopping festivals; First 100 days are critical for new product launches. (2018). Nielsen. Retrieved July 16, 2019, from https://www.nielsen.com/cn/en/insights/article/2018/94-percent-of-consumers-in-china-haveparticipated-in-shopping-festivals/

Five trends shaping the future of e-commerce in China. (2018). World Economic Forum. Retrieved July 18, 2019, from https://www.weforum.org/agenda/2018/09/five-trends-shaping-the-future-of-ecommerce-in-china/

Goffman, E. (1967). Interaction ritual: Essays on face to face behavior. Garden City, NY: Anchor.

Ho, D. (1976). On the concept of face. American Journal of Sociology, 81(4), 867-884.

Huffaker, D. (2006, February). Teen Blogs Exposed: The Private Lives of Teens Made Public. Presented at the American Association for the Advancement of Science (AAAS). St. Louis, MO.

Liu, Q., Shi, X., Wang, X., \& Li, J. (2017). 5G Development in China: From Policy Strategy to UserOriented Architecture. Mobile Information Systems, 1-11. doi:10.1155/2017/2358618

Luxury Market. (2018). Fund Business Intelligence. Retrieved July 20, 2019, from https://www.fbicgroup.com/sites/default/files/SCR2018_7_Luxury_Market.pdf

McDonald, M. (2007). Corporate marketing and service brands. Moving beyond the fast-moving consumer goods model. European Journal of Marketing, 3(5), 3-4.

Millennials. Coming of Age. (2015). Goldman Sachs. Retrieved July 13, 2019, from https:/www.goldmansachs.com/insights/archive/millennials/

Ming, Q., \& Zhongtao, S. (2017). Research on the Evolution, Effectiveness, and Trends of Chinese ECommerce Business Model. Industrial Economics.

Oxley, J. E., \& Yeung, B. (2001). E-Commerce Readiness: Institutional Environment and International Competitiveness. Journal of International Business Studies, 32(4), 705-723. doi:10.1057/palgrave.jibs. 8490991

Regular Press Conference of the Ministry of Commerce. (2019). Ministry of Commerce People's Republic of China. Retrieved July 11, 2019, from http://english.mofcom.gov.cn/article/newsrelease/press/201902/20190202837696.shtml

Retail Ecommerce Sales in China, 2016-2021. (2019). eMarketer. Retrieved July 13, 2019, from https://www.emarketer.com/Chart/Retail-Ecommerce-Sales-China-2016-2021-billions-change-ofworldwide-retail-ecommerce-sales/209064

7 trends as e-commerce enters Digital 3.0 era. (2015). Kantar Retail. Retrieved July 12, 2019, from available at: https://cn-en.kantar.com/business/retail/2015/7-trends-as-e-commerce-enters-digital30-era/

Stankovic J.A. (2014). Research directions for the Internet of Things. IEEE Internet Things J., 1(1), 3-9.

The China Academy of Information and Communications Technology. (2018). CAICT Insight on ICT2018. Retrieved July 17, 2019, from http://www.caict.ac.cn/english/yjcg/ict/201805/t20180530_173188.htm

The New China Playbook -Young, Affluent, E-Savvy Consumers Will Fuel Growth. (2015). Boston Consulting Group. Retrieved July 14, 2019, from 
http://www.bcg.com.cn/export/sites/default/en/files/publications/reports_pdf/BCG-The-NewChina-Playb

The State of Ecommerce in China in 2014. (2014). eMarketer. Retrieved July 18, 2019, from https://www.emarketer.com/Article/State-of-Ecommerce-China-2014/1011139

Top 10 online retailers: How the largest online retailers in the world fared in 2018. (2019). Internet Retailer. Retrieved July 17, 2019, from https://www.digitalcommerce360.com/2019/03/14/top10-online-retailers/

Understanding China's new consuming class - the millennials. (2018). Fund Business Intelligence. Retrieved July 15, 2019, from https://www.fbicgroup.com/sites/default/files/CCS series01.pdf

Wang, Y., Wang, Y., \& Lee, S. (2017). The Effect of Cross-Border E-Commerce on China's International Trade: An Empirical Study Based on Transaction Cost Analysis. Sustainability, 9(11), 2028. doi:10.3390/su9112028

Weber, L. (2007). Marketing to the social web: How digital customer communities build your business. Hoboken, NJ: John Wiley \& Sons.

Wong, N., \& Ahuvia, A. (1998). Personal taste and family face: Luxury consumption in Confucian and Western societies. Psychology \& Marketing, 15(5), 423-441.

Wu, C. (2017). Chinese E-commerce Legislation Current Situation, Problems and Ways to Improve. DEStech Transactions on Social Science, Education and Human Science, (APME). doi:10.12783/dtssehs/apme2016/8104

Yuxin, M., \& Liang, Z. (2016). Big Data Age - Research on Frontier Issues of E-Commerce Ethics. Northeastern University Press.

Zhao, K. (2015). Research on consumer online purchasing decision and its influencing factors in China. Retrieved July 18, 2019, from https://pdfs.semanticscholar.org/e6f2/4262c65b7a028c9d97e7c28cd8b950eaadb3.pdf

Zhou, N., \& Belk, R. (2004). Chinese consumer readings of global and local advertising appeals. Journal of Advertising, 33(3), 63-76.

Zhou, Z., \& Nakamoto, K. (2000). Price perceptions: A cross-national study between American and Chinese young consumers. Advances in Consumer Research, 28, 161-168.

Zhou, T., Lu, Y., \& Wang, B. (2011). A Comparative Analysis of Chinese Consumers' Increased vs. Decreased Online Purchases. Journal of Electronic Commerce in Organizations, 9(1), 38-55. doi:10.4018/jeco.2011010103 